\title{
Level of Education as the Determinant Factor of Obstetric Outpatients' Knowledge about Intra Uterine Device in Kramat Jati Public Health Center
}

\author{
Tingkat Pendidikan sebagai Faktor Determinan Pengetahuan Pasien \\ Poliklinik Kebidanan mengenai Alat Kontrasepsi Dalam Rahim \\ di Puskesmas Kecamatan Kramat Jati
}

\author{
Rinto Hariwibowo, Risca Marcelena, Rudy Kurniawan, Sandra Listiarini \\ Shabrina R. Putri, Silvy Firdaus, Dhika Prabu, Fernandi Moegni \\ Department of Obstetrics and Gynecology \\ Faculty of Medicine University of Indonesia/ \\ Dr. Cipto Mangunkusumo General Hospital \\ Jakarta
}

\begin{abstract}
Objective: To know the main factor affecting the knowledge of obstetric outpatients about intra uterine device (IUD).

Method: This is across sectional study involving 106 subjects who were selected by a consecutive random sampling in obstetric outpatients clinic, Kramat Jati Public Health Center, Jakarta. Data were obtained from guided questionnaire. There are several dependent variables, including the knowledge level of respondents toward IUD. Meanwhile, there are also independent variables, including education level, job, number of children, history of contraception use, and sources of information. The knowledge score $>60 \%$ is considered good. Afterwards, the data was evaluated with multivariate analysis with binary logistic regression.

Result: The study found association between the rate of knowledge with the level of education $(\mathrm{p}=0.015)$ and history of contraceptive usage $(\mathrm{p}=0.022)$. In multivariate analysis, it appeared that education level was the determinant factor, with the rate of low knowledge 2.6 times higher in the low education group.
\end{abstract}

Conclusion: Level of education are the determinant factor of obstetric outpatients' knowledge about intra uterine device in Kramat Jati Public Health Center.

[Indones J Obstet Gynecol 2012; 36-1:43-7]

Keywords: IUD, knowledge, level of education

\begin{abstract}
Abstrak
Tujuan: Untuk mengetahui faktor utama yang memengaruhi pengetahuan pasien poliklinik kebidanan mengenai alat kontrasepsi dalam rahim (AKDR).

Metode: Penelitian ini merupakan studi potong lintang yang melibatkan 106 subjek yang terpilih dengan metode consecutive sampling di poliklinik kebidanan, Puskesmas Kramat Jati, Jakarta. Data didapatkan melalui kuesioner terpimpin. Terdapat variabel bergantung dalam penelitian ini, yakni tingkat pengetahuan, dan variabel bebas, yakni tingkat pendidikan, jumlah anak, riwayat penggunaan kontrasepsi dan sumber informasi lainnya. Nilai $>60 \%$ dianggap sebagai memiliki tingkat pengetahuan yang baik. Kemudian, dilakukan analisis multivariat untuk mengetahui faktor yang paling berperan.

Hasil: Didapatkan adanya hubungan bermakna antara tingkat pengetahuan responden dengan tingkat pendidikan $(p=0,015)$ dan riwayat $K B(p=0,022)$. Hasil multivariat menunjukkan bahwa tingkat pendidikan merupakan faktor determinan, di mana tingkat pengetahuan yang buruk meningkat 2,6 kali pada kelompok responden dengan tingkat pendidikan rendah.
\end{abstract}

Kesimpulan: Tingkat pendidikan menjadi faktor utama dalam pengetahuan pasien di poliklinik kebidanan terhadap AKDR di Puskesmas Kramat Jati, Jakarta Timur.

[Maj Obstet Ginekol Indones 2012; 36-1:43-7]

Kata kunci: $A K D R$, pengetahuan, tingkat pendidikan

Correspondence: Rinto Hariwibowo. Department of Obstetrics and Gynecology Faculty of Medicine University of Indonesia/ Dr. Cipto Mangunkusumo Hospital, Jakarta. Telephone: 0811237081. Email: dhika_prabu@yahoo.co.id

\section{INTRODUCTION}

Maternal and child health are an essential development parameters of a nation, and it is included in the Millenium Development Goals (MDGs) that strive to lower Maternal Mortality Rate (MMR) to 102 per 100,000 births in 2015.,

According to the Indonesia Demographic and Health Survey (IDHS), MMR in Indonesia decreases from 450 per 100,000 births in 1986 to 307 per
100,000 births in 2002 , and 228 per 100,000 births in 2007. ${ }^{3}$ Despite the improvement, the MMR target of the MDGs in 2015 would still be hard to achieve without further intervention. One example of such intervention is the family planning program.

Contraceptions are expected to lower unwanted/ unexpected pregnancies which would also lower the risk of pregnancy-associated complications. Con- 
traceptive use is increasing in married women aged $15-49$ years from $57.4 \%$ in 1997 to $60.3 \%$ in 2003 , but with the current situation, it is projected that until 2015 there will be 4 millions births per year that will need extra cautions. ${ }^{1,2}$

Several contraceptive methods have been used in the population, from condoms to IUDs. IUDs (also known as "spirals" among Indonesians), as one of the modern contraceptive methods, are highly efficient with 0.6 to 0.8 births per 100 women in the first year of usage. ${ }^{4}$ Unfortunately, merely $83 \%$ married or ever-married women actually know about IUDs. IDHS reported a decrease in IUDs usage from $13 \%$ in 1991 to $5 \%$ in 2007.3

The low interest of IUDs among society can be observed by the number of IUDs installed in various health care facilities, compared to other contraceptive methods. In Kramat Jati Public Health Center, IUDs installment rate is only $3.62 \%$ of all patients visiting for contraceptions, only higher if compared to implants (1.61\%).

Based on the observation above, the authors felt the need to analyze the community's knowledge, attitude, and behaviour (KABs) relating to IUDs, to further identify factors that affect the KABs.

KABs are inter-related in one series. Knowledge is the result of thought through the senses which will have an impact on attitude, which will further be implemented to behaviour. ${ }^{5}$ The authors restrict the analysis to the knowledge of the community relating to IUDs and factors affecting it, while still giving the description of the attitude and behaviour. Hopefully, the result of the analysis can be useful in determining future policies which can be adjusted to the community's KABs.

\section{METHOD}

This is a cross-sectional study, conducted from October $10^{\text {th }} 2011$ until October $21^{\text {st }} 2011$ in Kramat Jati Primary Health Care, East Jakarta. The sample of this study came is all married female patients who came to obstetric outpatient clinic at Puskesmas Kramat Jati. Samples were selected consecutive sampling method with total samples 106 patients.

Obtained data were primary data from guided questionnaire. There were two variables in this study, independent variable and dependent variable. Dependent variable includes knowledge level of the respondents toward IUD. Meanwhile, independent variables include education level, occupation, number of children, history of contraception use, and sources of information.

To analyze the relationship of the respondent's knowledge level with the independent variables, categorized into two groups, we used Chi square test with $\mathrm{p}$ value $<0.05$ to be considered statistically significant. Education level was divided into high education level (at least graduated from high school) and low education level (did not graduated from high school) based on nine years compulsory learning. Occupation type was divided into works and does not work. Number of children were divided into $\leq 2$ children and $>2$ children based on the policy of Badan Kependudukan dan Keluarga Berencana Nasional (BKKBN). History of contraception used were divided into IUD users and non-IUD users. Sources of information were divided into medical personnel and nonmedical personnel. Level of knowledge, attitude, and behavior were divided into good and less based on the results of questionnaire, using scoring system: good if respondent can give at least $60 \%$ right answer for questions about knowledge and behavior and $70 \%$ for questions about attitude. We distinguished it by minimum criteria to achieve the expected behavior based on validated questionnaire. After that, a multivariate analysis was performed with binary logistic regression test to find determinant factor of the significant variables. We used SPSS 16 to do statistical analysis.

\section{RESULTS}

There are 106 respondents that were collected to be the research subject.

Table 1. Respondent's Characteristic $(n=106)$

\begin{tabular}{lc}
\hline \hline Variable & Respondent \\
\hline Age (year), (SD) & $29( \pm 5.904)$ \\
Education & $74(69.8 \%)$ \\
High $(\geq$ SMA) & $32(30.2 \%)$ \\
Low $(<$ SMA) & \\
Occupation & $24(22.6 \%)$ \\
$\quad$ Working & $82(77.4 \%)$ \\
$\quad$ Not Working & $17(16 \%)$ \\
Number of children & $89(84 \%)$ \\
$\leq 2$ & $8(7.5 \%)$ \\
$>2$ & $98(92.5 \%)$ \\
Contraception Method & $33(31.1 \%)$ \\
IUD & $73(68.9 \%)$ \\
$\quad$ Non-IUD & \\
Information Resources & \\
Medic & \\
Non-medic
\end{tabular}


Of the 98 non-IUD contraceptive users, we found that the $15.1 \%$ of the respondents were using pill, $37.7 \%$ were using injection, and $4.7 \%$ were using implants and $33 \%$ were not using any contraception.

The data that had been collected is then analyzed and the results were shown in Table 2 . We found that the majority of respondents have a good knowledge and practice toward the IUD. However, almost all of the respondents have unfavorable attitude toward the IUD.

Table 2. Knowledge, Attitude and Practice Level for IUD

\begin{tabular}{cc}
\hline \hline Variable & Total Respondent \\
\hline Knowledge & \\
Good & $65(61.3 \%)$ \\
Poor & $41(38.7 \%)$ \\
Attitude & \\
Good & $7(6.6 \%)$ \\
Poor & $99(93.4 \%)$ \\
Practice & \\
Good & $84(79.2 \%)$ \\
Poor & $22(20.8 \%)$ \\
\hline
\end{tabular}

Based on the statistical tests we performed on the variables of education level, history of contraception use, number of children, occupation, and information resources, we found a significant difference for education and the history of the use of contraception. Based on Chi-square test, we obtained $\mathrm{p}=0.015$ for level of education variable and odds ratio of 2.85 , with $95 \%$ CI 1.21 to 6.70 . It shows that the possibility of low-educated respon- dents had a poor knowledge about the IUD is 2.8 times more likely than high-educated respondents. Meanwhile, from Fisher test for the category of history of use of contraceptive methods, we obtained $p$ value of 0.022 . Based on the above data, we concluded that education and the history of the use of contraception is a factor that affect the level of knowledge about the IUD in obstetric clinic patients in Kramat Jati Health Center. (Table 3)

Table 4. Knowledge as Determinant Factor for IUD

\begin{tabular}{ccccc}
\hline \hline Variable & $\begin{array}{c}\text { Poor } \\
\text { Knowledge }\end{array}$ & $\begin{array}{c}\text { Good } \\
\text { Knowledge }\end{array}$ & p & $\begin{array}{c}\text { OR } \\
\text { (CI 95\%) }\end{array}$ \\
\hline Education & & & & \\
Low & $18(56.3 \%)$ & $14(43.8 \%)$ & 0.029 & $2.64(1.10-6.34)$ \\
High & $23(31.1 \%)$ & $51(68.9 \%)$ & - \\
\hline \hline
\end{tabular}

After multivariate analysis through binary logistic regression test with eligible variables $(p<0.25)$ was done, we concluded that the determinant factor for the level of knowledge about the IUD is education. The incidence of poor knowledge about the IUD will increase 2.6 times in the low-educated respondents. (Table 4)

\section{DISCUSSION}

According to Arbab et al, there was a significant difference between education level and knowledge about IUD $(\mathrm{p}<0.001)^{6}$ and it was backed up by another research which found the same thing too $(p=0.015)$. Purba, in his research, also gave similar statement, saying that there was a significant dif-

Table 3. Knowledge for IUD Based on Education, Contracepton Method, Number of Children, Occupation and Information Resources

\begin{tabular}{|c|c|c|c|c|}
\hline \multirow{2}{*}{ Variable } & \multicolumn{2}{|c|}{ Knowledge } & \multirow{2}{*}{ OR (95\%CI) } & \multirow[b]{2}{*}{$\mathbf{p}$} \\
\hline & Poor & Good & & \\
\hline \multicolumn{5}{|l|}{ Education } \\
\hline Low $(<\mathrm{SMA})$ & $18(56.3 \%)$ & $14(43.8 \%)$ & $2.85(1.21-6.70)$ & 0.015 \\
\hline High $(\geq$ SMA) & $23(31.1 \%)$ & $51(68.9 \%)$ & - & \\
\hline \multicolumn{5}{|c|}{ Contraception method } \\
\hline Non-IUD & $41(41.8 \%)$ & $57(58.2 \%)$ & & 0.022 \\
\hline IUD & $0(0 \%)$ & $8(100 \%)$ & - & \\
\hline \multicolumn{5}{|c|}{ Number of children } \\
\hline$\leq 2$ & $7(41.2 \%)$ & $10(58.8 \%)$ & $1.13(0.39-3.25)$ & 0.818 \\
\hline$>2$ & $34(38.2 \%)$ & $55(61.8 \%)$ & - & \\
\hline \multicolumn{5}{|l|}{ Occupation } \\
\hline Not working & $33(40.2 \%)$ & 49 (59.8\%) & $1.34(0.51-3.50)$ & 0.541 \\
\hline Working & $8(33.3 \%)$ & $16(66.7 \%)$ & - & \\
\hline \multicolumn{5}{|c|}{ Information resources } \\
\hline Non-medic & $30(41.1 \%)$ & 43 (58.9\%) & $1.39(0.59-3.30)$ & 0.447 \\
\hline Medic & $11(33.3 \%)$ & $22(66.7 \%)$ & - & \\
\hline
\end{tabular}


ference between education level and knowledge $(=0.025)^{7}$

Knowledge level increases simultaneously with higher level of education. There is more IUD user in high educational group, having better basic knowledge about IUD itself, rather than subjects from lower education group, who are mostly not using IUD. Subjects from high education level group are more capable in processing information given and are more able to differentiate which one is right or wrong.

Based on the study by Arbab et al, it is found that there is no correlation between occupation and knowledge about IUD $(\mathrm{p}=0.101){ }^{6}$ This research also found that there is no significant difference between occupation and knowledge about IUD, with $\mathrm{p}=0.541$. The knowledge in the working group is as good as the knowledge in non-working group, probably because nowadays we can access the information about IUD easily. ${ }^{8}$ Besides, not all non-working subject is coming from the low education level. The myth and rumor about IUD spreading in the community also play role in people's curiosity about it. Wanting to gain more information, people tend to actively ask about IUD to medical worker or non-medical personnel. ${ }^{9}$

There is a significant difference between contraception device used and knowledge level about IUD $(\mathrm{p}=0.022)$, where all subjects using IUD have good knowledge about it. This is caused by direct involvement of the subject themselves, whether it is before, in the moment, and after IUD attachment. Routine education to the subjects was also given when they come to the public health center to do routine check up.

Based on the study by Purba et al, there is no correlation between the level of knowledge and the number of the subjects' spawn $(p=0.16)$. It is shown that subjects with more than two kids have unsatisfying response to family planning and contraception service, and it is getting worse because the basic knowledge about it was not good. Similar thing is also found in this research with $\mathrm{p}=0.818$, but it differs in that the subject group with more than two kids have better knowledge because they get more education and family planning, including IUD.

Based on a study done by Basu et al, the source of information have an important role in the knowledge level $(p<0.05)$, where most information comes from medical provider. ${ }^{10}$ But there was also a study, which stated that most information comes from an informal source such as family and neighbours. Interpersonal communication with relatives has a great role in spreading the information about IUD, especially because the opportunity to see the medical providers is so little. Epsey et al said that family, friends, and mass media are major sources for information and opinion related to IUD. ${ }^{11}$ But in this research, we found the opposite result. There are no significant difference between information source and the level of knowledge $(p=$ 0.447). This may be caused by the education system in Kramat Jati Public Health Center, which is already good enough. Most subjects showed good knowledge about IUD despite the information source (medical provider or informal source such as family members). From this fact, we can say that it is true that information spreads in the community.

The result of this study showed us that education level is the determinant factor of knowledge level about IUD in the patients of obstetric clinic in Kramat Jati Public Health Center. Until this article is being written, we haven't found similar article doing multivariate analysis with the similiar variables.

In this study, the occurrence of subject having poor knowledge level increases 2.6 times higher in the subject with low education level. They tend to refuse to use IUD, thus there is no curiosity which can lead them into asking for more information. The general knowledge is also poorer in low education group. Thus, we can conclude that the low level of IUD knowledge is caused by low education level.

\section{CONCLUSION}

There is a significant relationship between level of education $(p=0.015)$ and a history of contraceptive methods used $(\mathrm{p}=0.022)$ with the knowledge level of respondents. Based on the results of multivariate analysis, we found that education level is a determinant factor in patients of obstetric outpatient clinic in.

\section{SUGGESTION}

Researchers suggest that education carried out by health workers and health centers should be further intensified. Based on the result that the deter- 
minant factor of IUD knowledge is education level, then the next target for intervention must be appropriate, e.g. in the group with low education. In this case, the education provided not only through counseling to patients who come to the outpatient clinic for consultation on contraceptive methods, but also to the community. Lower level of education in women is associated with a lower willingness to use contraceptives. Thus, health workers should be dropped directly into the community and not just wait. In addition, we recommend that further research should be done with other variables, also examined the relationship between knowledge, attitudes, and behavior itself.

\section{REFERENCES}

1. UNDP. Summary - Indonesia progress report on the MDGs 2005. United Nations Development Programme 2005 [cited 2011 October 25]. Available from: http://www.undp.or.id/ pubs/imdg2005/English/MDG_en2005.pdf

2. WHO. Trends in maternal mortality: 1990 to 2008 estimates developed by WHO, UNICEF, The World Bank. 2010.

3. Badan Pusat Statistik \& Macro International. Indonesia demographic and health survey 2007. Calverton: BPS \& Macro International; 2008.
4. Wiknjosastro H, ed. Ilmu Kandungan edisi 2. Jakarta: PT Bina Pustaka Sarwono Prawirohardjo. 2009

5. Gutin SA, Mlobeli R, Moss M, Buga G, Morroni C. Survey of knowledge, attitudes and practices surrounding the intra uterine device in South Africa. Contraception. 2011

6. Arbab AA, Bener A, Abdulmalik M. Prevalence, awareness and determinants of contraceptive use in Qatari women. East Mediterranean Health J 2011; 83(2):145-50.

7. Purba JT. Faktor-faktor yang mempengaruhi pemakaian alat kontrasepsi pada istri PUS di Kecamatan Rambah Samo Kabupaten Rokan Hulu tahun 2008. Universitas Sumatera Utara; 2009.

8. Hubacher D, Vilchez R, Gmach R, Jarquin C, Medrano J, Gadea A, et al. The impact of clinician education on IUD uptake, knowledge and attitudes: results of a randomized trial. Contraception 2006; 73(6):628-33.

9. Katz KR, Johnson LM, Janowitz B, Carranza JM. Reasons for the low level of IUD use in El Salvador. Int Fam Planning Perspectives 2002; 28(1):26-31.

10. Basu S, Kapoor AK, Basu SK. Knowledge, atittude and practice of family planning among tribals. J Family Welfare 2004; 50(1).

11. Espey BE. IUD-Related knowledge, attitudes and practices among Navajo Area Indian Health service providers. Persp Sex Reprod Health 2003; 35:169-73. 